\title{
Angst About Academic Writing: Graduate Students At The Brink
}

\author{
Barbara Holmes, Winona State University, USA \\ Theresa Waterbury, Winona State University, USA \\ Eric Baltrinic, Winona State University, USA \\ Arielle Davis, Winona State University, USA
}

\begin{abstract}
This paper offers some insights into the anxieties graduate students bring into the classroom about academic or technical writing. In this qualitative study, a focus group of graduate students was utilized to describe the specific negative feelings, attitudes and experiences held about writing. Findings suggest that students were able to identify three main reasons or causes of writing anxiety: (1) lack of confidence in writing ability (2) lack of time to devote to writing activities and (3) lack of skills in utilizing scholarly resources. Participants also suggest that colleges and universities take more proactive steps in implementing strategies early in the matriculation process to support graduate students in acquiring writing competency. This exploration suggests that there is still much to be learned from graduate students about what colleges and universities can do to improve writing literacy, help graduate students acquire writing self-efficacy and create a culture of writing expectations.
\end{abstract}

Keywords: Writing Anxiety; Graduate Student Writing; Writing Angst



cademic writing continues to generate anxiety among graduate students. There appears to be a real fear of committing thoughts and ideas to writing in a scholarly environment. Merc (2016) concluded that writing anxiety among graduate students is particularly prevalent in graduate courses that specifically focus on research methods training, and the dissertation writing process. Sevidy-Benton and O'Kelly (2015) further warned that "anxiety about the research required in a class may overshadow any benefits the students may get from the content" (p. 47). Students admitted to graduate study are among the highest achieving students in the academy, therefore, the acquisition of writing skills by this population of students remains a concern.

The Writing Center at UNC-Chapel (2016) explains that writing anxiety encompasses a wide range of worrisome and apprehensive feelings about writing that causes students to have negative experiences with writing. Hjortsho (2001) suggests that writing anxiety is situational and that students may enjoy writing in one setting and be petrified by writing in higher stakes situations. Consequently, how we address writing anxiety may need to be grounded in the context or situation surrounding the writing assignment. The University of Texas Writing Center (2016) further identified several situations that can cause writing anxiety for students:

1. Adapting to a new style of writing, such as the first semester of a college writing course or a form of writing the student is not used to (a research paper, a senior thesis, a dissertation, etc.)

2. Writing for a tough audience (i.e., a professor who's been highly critical of previous work)

3. Thinking about criticism received on writing in the past (even if the person who has criticized is not the audience for your paper)

4. Tight deadlines for the submission of the writing assignment

5. Not clearly and completely understanding the writing assignment

Additionally, Cone (2016) postulated that writing anxiety may result from a variety of social and academic factors. Students worry about class grades, paper deadlines, fear of failure, life or social issues, a competitive nature or pressure from significant others to be a high achiever. Researchers noted, that students may fear a professor who in their judgment is intimidating or difficult to please. Understanding and being aware of these triggers may be helpful in providing assistance to students who are struggling with negative feelings about writing. 
In a seminal study on why graduate students exhibit poor writing (Bloom, 1982) concluded that graduate students are plagued with the same problems of other anxious writers: lack of confidence, poor time management, chronic procrastinators, dislike writing and suffer from fear of having the writing critiqued. This investigation situates the inquiry in 2016 to explore the nature of graduate student writing anxiety in a research and scholarship class.

Holladay (1981) also researched attitudes toward writing, and concluded that teachers can help lessen writing anxiety by using different teaching strategies. Holladay summarized the following characteristics of students with writing anxiety:

1. They are frightened by a demand for writing competency

2. They fear evaluation of their writing because they think they will be rated negatively

3. They avoid writing whenever possible

4. When they are forced to write, they behave destructively

These behaviors usually result in a poorly developed writing product, which then reinforces the writing anxiety.

Onwuegbuzie (1998) conducted a study to determine the relationship between learning style and writing anxiety among graduate students utilizing The Writing Apprehension Test and the Productivity Environmental Preference Survey. From collected student responses, the researcher found that graduate students with the highest levels of writing anxiety lacked self-motivation, preferred structure, were peer-oriented learners, were authority-oriented learners, and did not like to undertake difficult tasks in the afternoon. Given that research methods classes tend to be highly structured, high levels of anxiety continue to persist.

\section{Perspectives of a Graduate Department Chair}

From the department chair perspective, the problem of graduate student writing deficiencies is one of long standing in the program of preparation. A graduate department chairperson, offered the following comments:

"Over the last seven years, I have witnessed the anxiety level of graduate students rise when they are required to write academic papers. During this time, I have made observations based on student papers and assignments, informal student interviews, and discussions with faculty. There are three themes I have observed: lack of academic writing skills, lack of time to access writing resources, and self-consciousness."

"We have two distinct populations of graduate students at our institution: working adults and traditional students (students who enroll in the program directly after completing their undergraduate degree). Many of the working adults have not written an academic paper in the last ten years. They are skilled at writing short notes and personal letters, but are not familiar with academic writing. The traditional student population is accustomed to multiple choice and short answer exams with a moderate focus on academic writing. Students, therefore, lack the skills needed to clearly articulate their thoughts into words and many lack APA knowledge."

"Typically, graduate students are not on campus during the day. Our students balance work, school, and family, so it is difficult for them to find the time needed to strengthen their writing skills. The campus has a writing center, but graduate students find it challenging to attend during the open hours. Finally, students seem to be self-conscious when we recommend they seek writing assistance. They are leaders in their organizations and struggle with being vulnerable."

This department continues to explore strategies for addressing writing anxiety at the graduate level and is considering front loading academic writing standards in the initial classes students take upon entry into the program. 


\section{Perspectives of a Counselor Education Graduate Faculty Member}

There is a general understanding among counselor educators that graduate students need academic writing skills to be successful in their future jobs (Hill, 2004), particularly for those students who assume faculty roles requiring scholarly productivity (Magnuson, Norem, \& Haberstroh, 2001). Academic writing is a ubiquitous activity for graduate students. Counselor education graduate students engage in academic writing as part of course assignments, the creation of scholarly works, and as a means to learn about the writing and publication process.

Similar to students in other disciplines (Bloom, 1982; Onwuegbuzie, 1998), counselor education graduate students experience challenges to academic writing. Academic writing can be stressful for students given the writing demands in most graduate training programs. Some authors believe that graduate students' writing challenges are due to inadequate preparation in academic writing (Lambie, Sias, Davis, Lawson, \& Akos, 2008), while others suggest there is a lack of counselor education literature to help educators facilitate the development of students' writing skills (McDonald, 2011). Acknowledging the challenges academic writing poses to graduate students, a counselor educator was asked to reflect on his experience mentoring graduate students in writing. He offered the following observations and suggestions:

1. Students who believe they are good writers often produce examples of good writing, and the reverse is also true. So, focusing individual attention on those less-efficacious writers can be helpful as well as pairing better writers with struggling writers through peer-review activities in the classroom. Be sure to model good writing, even during email exchanges.

2. Help students learn about writing by incorporating the Publication Manual of the American Psychological Association (2010) into your class discussions and required assignments. More specifically, have students read and discuss sections of the manual such as chapter 3 , which outlines tips for writing clearly and concisely. It is surprising how many students do not own or read this manual, opting for web resources instead.

3. Provide accurate written feedback to students about academic writing. Refer students to specific pages in the APA publication manual and other resources containing examples. Students need to navigate the resources and use the manual to help them solve writing problems, with faculty support. And most of all, practice your writing. Ask yourself: Do my corrections and feedback provide clear and concise feedback to the reader?

The development of students' professional writing voice "takes practice" (McDonald, 2011, p. 124). To better assure graduate students readiness for future job demands, educators need to focus on the development of classroom-level resources and teaching tools to facilitate the development of academic writing skills.

\section{METHOD}

This study identified the perceptions of enrolled leadership education students with their academic writing angst. A focus group methodology was used to gather qualitative data during the students' first research class.

\section{Participants}

Thirteen graduate students participated in the focus group =ranging in age from $24-50$ years. The study took place at a mid-western university which has regional authority to offer graduate degrees. Demographic data included gender and credit hours completed in the program. Fifty four percent of the respondents were male, $15 \%$ had completed fewer than 12 hours and $50 \%$ completed 15 credits or more graduate credits.

\section{PROCEDURES}

The focus group began with the instructor encouraging graduate students to reflect on their own writing skills by asking them to write for ten minutes at the beginning of a class on a topic. Topic areas for students' reflective writing were provided to students by the instructor. The following writing prompts were provided to encourage students to get words on paper. 
1. Transitioning into scholarship: Ten big ideas for graduate students

2. What graduate students need to be thought leaders in Education

3. Mastering the art of academic writing graduate student perspectives and transitions

4. Lewin's theory of change and the graduate student experience

5. Traits graduate students need to persist to program completion

6. Angst about Academic Writing: Graduate Students at the Brink

Participants selected the writing prompts they were most comfortable with. This free writing exercise generated multiple responses and students were able to express feelings about the writing process and their experiences as graduate students. In this safe writing environment, students seem to enjoy putting their frustrations about writing on paper. This procedure allowed full disclosure of each student's responses and as the class progressed, students openly discussed their writing anxiety with each other. After students had engaged in writing and open discussion for approximately 15 minutes, a focus group session was convened to continue to explore students' feelings about writing. The focus group session was guided by the following research questions:

1. What are the specific anxieties that graduate students have about scholarly writing?

2. How do graduate students describe their fear of academic writing?

3. What recommendations do graduate students have for institutions to address graduate writing anxieties?

\section{RESULTS}

Focus group participants' lack confidence in writing abilities surfaced repeatedly as a concern of students. One student expressed doubt that good writing would ever occur. Another student responded, "Writing is like learning a foreign language and I am not very good at it." A member of the class served as recorder and captured the ideas expressed by participants. The recorder projected responses on a screen for the entire class to visualize. Participants grouped similar responses together and discussed similarities and differences. The discussion yielded four emergent themes:

Emergent Theme 1: Lack of confidence in scholarly writing ability

Despite many students having high academic grade point averages, students lacked confidence in their ability to sufficiently decode a scholarly writing assignment and respond in an effective manner. This finding aligns with the work of Holladay (1981) who reported that graduate students have high fear of receiving negative feedback on their writing. The findings suggest graduate students fear different aspects of academic writing including lack of sufficient time for writing, not achieving success, writing with clarity, not having appropriate sources, the task of gathering relevant supporting data, sounding uninformed, and a lack of confidence about chosen topics.

Emergent Theme 2: Lack of time to dedicate to writing tasks

The study sample included experienced practitioners who were balancing multiple priorities in the workplace, home, community, and church. Participants did not place high priority on academic writing and consequently time was not allocated for the writing process. This finding reflects the work of Bloom (1982) who reasoned that anxious writers tend to be chronic procrastinators with poor time management skills.

Emergent Theme 3: Lack of skills in identifying and utilizing scholarly resources

The graduate department chair postulated that time away from writing may explain why students have negative attitudes toward writing. There is little familiarity with finding academic sources, accessing online databases, and utilizing library resources which impedes the literature review process. Holladay (1981) explains that students lacking writing competency hold on to negative experiences with writing at the undergraduate level.

Emergent Theme 4: Institutions share the responsibility for improving graduate student writing

Participants offered several suggestions for improving the graduate writing experience at the university. Graduate students identified the following changes for institutions to consider: 
1. Teach APA guidelines in initial graduate classes and hold students accountable for properly formatting papers.

2. Provide graduate students with examples of good papers, properly formatted

3. Establish high expectations for scholarly writing at the beginning of graduate studies

4. Have writing resources readily available outside of the formal classroom

5. Require a writing orientation for graduate students upon entry into graduate study

6. Provide research tools for graduate students early in program studies.

7. Provide more one-on-one writing interaction with instructors focused on writing

8. Strengthen writing at the undergraduate level to prepare students for graduate level writing

9. Create student habits of writing to include finding and using sources, citations, and credible sources and embed these activities in graduate coursework

10. Create and foster more peer review networks for writing for online and traditional students

\section{DISCUSSION}

Overall, the preliminary findings from the focus group provide support for the need to actively work to change graduate students' attitudes about writing (Bloom, 1982; Onwuegbuzie, 1998). More specifically, students' perceptions, experiences, and attitudes toward writing can influence their feelings about the act of writing. Scholars have pointed out the significance of the students' point of view and students need to be empowered to express perspectives held about writing while matriculating in the academy.

Students expressed that feeling unfamiliar with "the rules of the game" and what is expected of academic writers in a university setting posed barriers to their writing. The development of a new program could enact a new role for writing, from both faculty and staff perspectives. Hayes (1978) concluded that increasing the amount of writing does little without attending to the writing process itself. The program would need to focus on writing structure and feedback, from both instructor and peers. As Sperling and Freedman (2001) have shown, students that have received feedback on drafts from their professors tend to misunderstand that feedback and feel obligated to revise their papers in ways that do not always improve the paper.

Findings support the use of writing resources as a means to reduce anxiety and provide tools to students. For example, Hjortshoj (2001) writes about his experiences working with university students experiencing writing block. The author further explains the transitional nature of most writing blocks and the importance of finding support from others when working on long projects. Hjortshoj's (2001) book is a particularly excellent resource that captures the experiences of students struggling with writing, which could, in turn, be used as a guide-grounded in shared experiences across university settings-- for advanced undergraduates and graduate students.

\section{IMPLICATIONS AND FUTURE RESEARCH}

These preliminary findings suggest that graduate student anxiety about academic writing remains a current problem in the academy. Graduate students suggest that writing instruction should begin earlier in the college experience along with training in how to find and utilize academic resources. Efforts to improve graduate student writing may include changes in instructional practices, instructor expectations, and frequent opportunities to produce scholarly writing.

Faculty supports provided to graduate students could improve students' academic writing according to all participants in this study $(\mathrm{N}=13)$. The task of providing support for students' academic writing becomes more manageable as faculty members learn how to integrate high expectations for scholarly writing, writing instruction, writing selfefficacy among students and writing feedback that encourages students to write more. Good teachers can influence good writing. Future studies could investigate students' perspectives on a wider scale using larger samples. In-depth qualitative interviews could be used to build on information obtained in future focus groups. 


\section{REFERENCES}

American Psychological Association. (2010). Publication Manual of the American Psychological Association (6th ed.) Washington, DC: American Psychological Association.

Bloom, L. (1982). Why graduate students can't write: Implications of research on writing anxiety for graduate education. Journal of Advanced Composition, 2(1/2), 103-117.

Cone, L. (2016). Confronting writing anxiety. University of Richmond Writing Center: http://writing2.richmond.edu/writing/wweb/writinganxietyprint.html

Hayes, J. R. (1978). Cognitive psychology: Thinking and creating. Homewood, Illinois: Dorsey Press.

Hill, N. R. (2004). The challenge experienced by pretenured faculty in counselor education: A wellness perspective. Counselor Education and Supervision, 4, 135-146.

Hjortshoj, K. (2001). Understanding writing blocks. Oxford: Oxford University Press.

Holladay, S. (1981) Writing anxiety: What research tells us. ERIC Number: ED216393 Record Type: RIE

Lambie, G. W., Sias, S. M., Davis, K. M., Lawson, G., \& Akos, P. (2008). A scholarly writing resource for counselor educators and their students. Journal of Counseling \& Development, 86, 18-25.

Magnuson, S., Norem, K., \& Haberstroh, S. (2001). New assistant professors of counselor education: Their preparation and their indication. Counselor Education and Supervision, 40, 220-229.

McDonald, E. K. (2011). Teaching the 6th edition of APA style of writing n counselor education. Journal of Counselor Preparation and Supervision, 3(2), 124-145.

Merc, A. (2016). Research anxiety among Turkish graduate ELT students. Current Issues in Education, 19(1), 1-15.

Onwuegbuzie, A. (1998). The relationship between writing anxiety and learning styles among graduate students. Journal of College Student Development, $39(6)$.

Sevidy-Benton, A. L., \& O'Kelly, M. K. (2015). Connecting theory to practice: Making research real for graduate students. Handbook of Research on Scholarly Publishing and Research Methods, (38).

Sperling, M., \& Freedman, S. W. (2001). Review of writing research. In V. Richardson (Ed.), Handbook of Research on Teaching (4th ed., 370-389). Washington, DC: American Educational Research Association.

University of North Carolina- Chapel Hill Writing Center. (2016). Writing Anxiety. Retrieved from http://writingcenter.unc.edu/

University of Texas Writing Center. (2016). Reducing Writing Anxiety. Retrieved from http://academics.utep.edu/Default.aspx?tabid=65899 